\title{
The triggering of subglacial lake drainage during rapid glacier drawdown: Crane Glacier, Antarctic Peninsula
}

\author{
Ted A. SCAMBOS, ${ }^{1}$ Etienne BERTHIER, ${ }^{2}$ Christopher A. SHUMAN ${ }^{3,4}$ \\ ${ }^{1}$ National Snow and Ice Data Center, 1540 30th Street, CIRES, Campus Box 449, University of Colorado, Boulder, \\ CO 80309-0449, USA \\ E-mail: teds@nsidc.org \\ ${ }^{2}$ CNRS, Université de Toulouse, Legos, 14 avenue Edouard Belin, 31400 Toulouse Cedex, France \\ ${ }^{3}$ Goddard Earth Science and Technology Center, University of Maryland, Baltimore County, MD 21228, USA \\ ${ }^{4}$ NASA Goddard Space Flight Center, Greenbelt, MD 20771, USA
}

\begin{abstract}
Ice surface altimetry from ICESat-1 and NASA aircraft altimeter overflights spanning 200209 indicate that a region of lower Crane Glacier, Antarctic Peninsula, shows an unusual temporal pattern of elevation loss: a period of very rapid drawdown $\left(\sim 91 \mathrm{~m} \mathrm{a}^{-1}\right.$ between September 2004 and September 2005) bounded by periods of large but more moderate rates (23 $\mathrm{m} \mathrm{a}^{-1}$ until September 2004; $12 \mathrm{~m} \mathrm{a}^{-1}$ after September 2005). The region of increased drawdown is $\sim 4.5 \mathrm{~km} \times 2.2 \mathrm{~km}$ based on satellite (ASTER and SPOT-5) stereo-image digital elevation model (DEM) differencing spanning the event. In a later differential DEM the anomalous drawdown feature is not seen. Bathymetry in Crane Glacier fjord reveals a series of flat-lying, formerly subglacial deeps interpreted as lake sediment basins. We conclude that the elevation-change feature resulted from drainage of a small, deep subglacial lake. We infer that the drainage event was induced by hydraulic forcing of subglacial water past a downstream obstruction. However, only a fraction of Crane Glacier's increase in flow speed that occurred near the time of lake drainage (derived from image feature tracking) appears to be directly attributable to the event; instead, retreat of the ice front off a subglacial ridge $6 \mathrm{~km}$ downstream of the lake is likely the dominant cause of renewed fast flow and more negative mass balance in the subsequent 4 years.
\end{abstract}

\section{INTRODUCTION}

A resurgence of interest in subglacial hydrology, particularly in the Antarctic ice sheet system, has been sparked by the recent successes of satellite altimetry and interferometric synthetic aperture radar (SAR) in detecting subtle localized elevation changes. These are interpreted as active, volumechanging subglacial lakes interconnected by drainage systems (Rémy and Legrésy, 2004; Gray and others, 2005; Wingham and others, 2006; Fricker and others, 2007; Stearns and others, 2008; Fricker and Scambos, 2009). Hundreds of these active subglacial systems have now been identified (Smith and others, 2009) and, in one case at least, they are shown to affect ice flow (Byrd Glacier; Stearns and others, 2008). Moreover, compilations of both radar reflection evidence and surface morphological indicators of larger subglacial water bodies (Siegert and others, 2005; Smith and others, 2009) show that not only are these also widespread but that they, too, can have important effects on ice flow (e.g. Bell and others, 2007).

Despite these advances, a class of subglacial water bodies remains largely unmapped: smaller pockets (less than a few ice thicknesses across) that remain stable. Since these features may not have a surface elevation change over time associated with them (which permits detection) and do not affect surface morphology significantly, they are detectable only by radio-echo surveys. These surveys are sparsely distributed. In the case of heavily crevassed outlet glaciers, it may be difficult to detect the subglacial water body even with radio-echo surveys. Recent modeling studies of subglacial melt rates (Pattyn, 2010) and the irregularity of both surface topography and bed elevation where they are mapped in detail (e.g. West Antarctica (Shabtaie and Bentley, 1988; http://www.ig.utexas.edu/research/projects/ agasea); East Antarctica (Bo and others, 2009; http:// www. Ideo.columbia.edu/ mstuding/AGAP/AGAP_GAMBIT_maps.html)) show that abundant sub-ice water is available and that there are numerous places where it may be trapped. As our ability to map the base of the ice sheet and detect the presence of subglacial water bodies improves, it is likely that we will find an ice-sheet bed surface as pocked with lakes as the current land areas that were formerly beneath ice sheets (e.g. the Canadian Shield and Scandinavia; Clarke, 2005).

These small stable water bodies, if widespread, represent an important potential contributor to mass-balance changes as a glacier responds to climate-driven changes in flow. In the case of retreating tidewater glaciers, as glacier mass imbalance increases, the surface slope generally increases as well. Changes in surface slope across a subglacial body of water must create subglacial pressure gradient changes, forcing the confined water to move in the downslope direction. The trapping mechanism that sustained the lake (bedrock sill, sediment plug or a local high in subglacial hydraulic potential) is tested, and if pressure changes are great enough it is breached. The water then drains into the subglacial environment downstream.

At Crane Glacier, an outlet glacier draining the eastern Antarctic Peninsula, we have mapped a case where such an ice-dynamics-driven (more broadly, climate-driven) slope change has apparently caused a subglacial water pocket to drain into the subglacial environment (Fig. 1). Crane Glacier is the largest of the outlet glaciers flowing into 


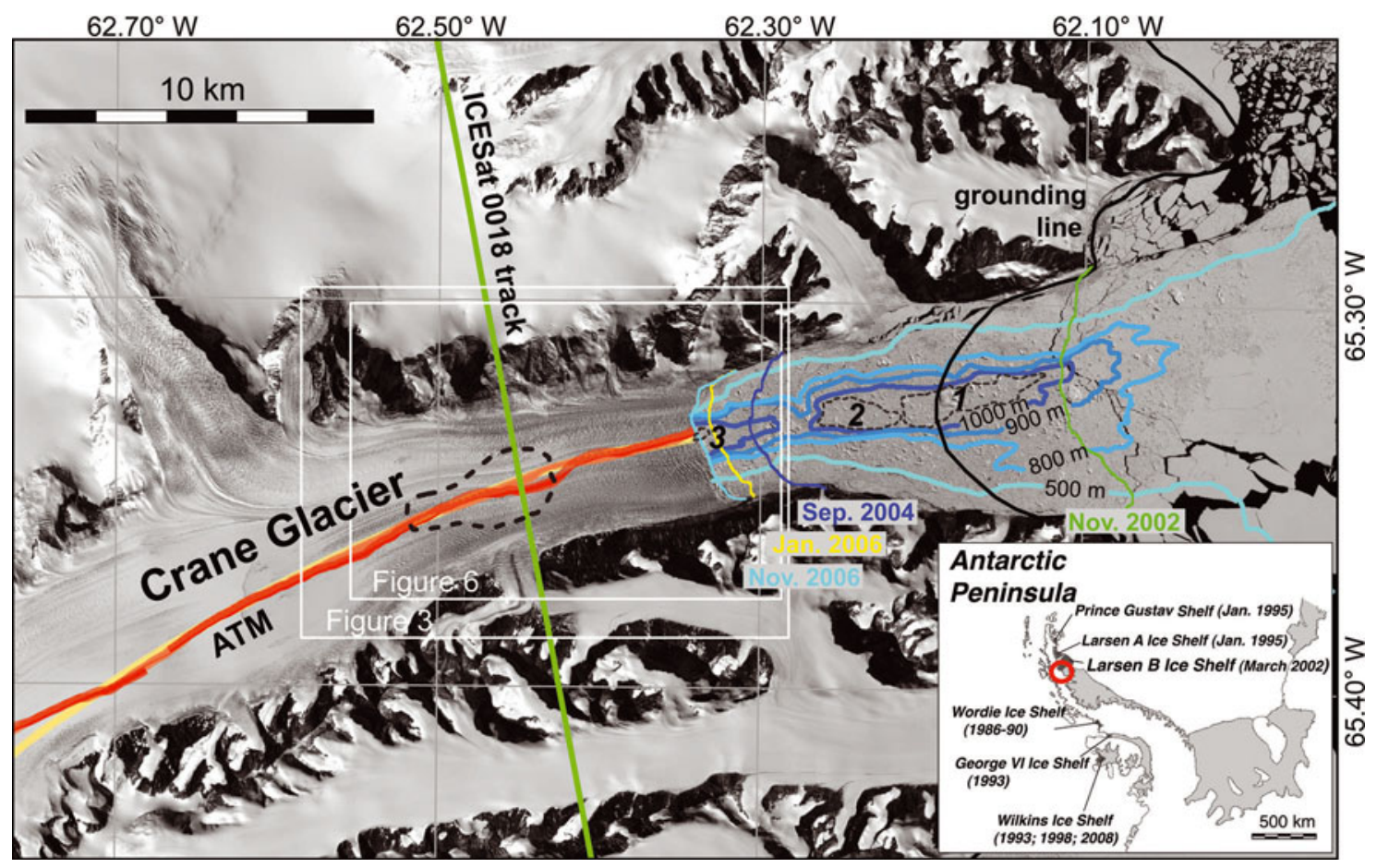

Fig. 1. Satellite image map of lower Crane Glacier and fjord. Inset: locator map of Crane Glacier, within the Larsen B embayment, Antarctic Peninsula; dates and extent of major ice-shelf break-up events for the region are shown. Main image is from SPOT-5 high-resolution stereo (HRS) sensor, acquired 25 November 2006. Recent airborne laser altimetry tracks (ATM: 2002, 2004 and 2008 in yellow, orange and red respectively) and satellite laser altimetry tracks (ICESat: 2003-09, straight green line) show significant elevation changes on the glacier, which are anomalously large in the irregular region at their intersection (interpreted in this study as resulting from a subglacial lake). Bathymetric contours of the fjord are from multi-beam sonar mapping in 2006 (personal communication from E. Domack, 2011). Numbers in the fjord (1,2 and 3) and dashed outlines represent flat sediment-filled basins interpreted as past subglacial lake deposits. Grounding line of 1998-2002 is from SAR interferometry (Rack and Rott, 2004). Ice-front locations for floating (November 2002) and grounded ice fronts are shown; since November 2006 the ice-front position has been essentially unchanged.

the embayment created by the loss of the Larsen B ice shelf in February-March 2002 (Scambos and others, 2004). Response of the several glaciers affected by the shelf loss was almost immediate. There was an acceleration in flow speed, with ice-front flow rates rising to six to eight times the pre-shelf-loss speed by late 2003 (Rignot and others, 2004; Scambos and others, 2004), rapid loss of the remaining floating tongues, and widespread new extensional crevassing. However, by early 2004, Crane Glacier had slowed significantly, to just twice the pre-break-up speed, before re-accelerating in 2005 (Hulbe and others, 2008). Shuman and others (in press) discuss the regional elevation changes and mass-balance response since shelf break-up.

In the following, we compile evidence from satellite and airborne laser altimetry, satellite stereo-image digital elevation models (DEMs) and image pair velocity maps that examine the period of renewed rapid changes on Crane in 2004, 2005 and 2006, concluding that some of this change was the result of subglacial lake drainage. However, retreat of the glacier front from a bedrock high in the Crane fjord, as mapped by bathymetry (Mueller and others 2006, fig. 1; personal communication from E. Domack, 2011), also played a role in the glacier evolution at the time of the inferred lake drainage. We compare the significance of the lake drainage and ice-front retreat on elevation change, ice flow and mass balance for Crane Glacier, and thereby gain some insight into the importance of a potential subglacial water feedback on retreating outlet glaciers.

\section{DATA SOURCES AND METHODS}

\subsection{ICESat-1 data}

The Ice, Cloud, and land Elevation Satellite (ICESat) provided global elevation mapping below $86^{\circ} \mathrm{S}$ between 20 February 2003 and 11 October 2009. ICESat carried an orbiting infrared $(1064 \mathrm{~nm})$ pulse-laser system that acquired ranging times to the surface (or intervening cloud or aerosol layers) at a $40 \mathrm{~Hz}$ rate, roughly equivalent to $172 \mathrm{~m}$ ground spacing (Zwally and others, 2002a; Schutz and others, 2005). Spot size of the laser pulse on the ground was nominally $70 \mathrm{~m}$ and varied depending on which laser was operating, although the majority of the data were acquired with a $50 \mathrm{~m}$ footprint (see http://nsidc.org/data/icesat/laser_op_periods.html 'Attributes' metadata table). The spacecraft was flown in both 8 and 91 day repeat track orbits, and the majority of the data were collected in a 33 day subcycle of the 91 day orbit. One orbit track (track 0018) crosses lower Crane Glacier. Out of 16 total track 0018 acquisitions over Crane Glacier, useful ice surface data were acquired on 10 of them (6 nearcomplete profiles and 4 partial profiles). Error of the ICESat elevation measurements over flat snow-covered terrain is $\sim 20 \mathrm{~cm}$ (Shuman and others, 2006). Shot-to-shot variations and small-scale differences between repeated profiles suggest an error of 2-3 $\mathrm{m}$ over the extremely rough ice of lower Crane Glacier (which has sub-laser-spot scale crevassing and seracs, especially after 2004). ICESat-1 data may be acquired from the US National Snow and Ice Data Center (NSIDC; http://nsidc.org/data/icesat). 
Table 1. Satellite images and image pairs used for elevation and velocity measurement

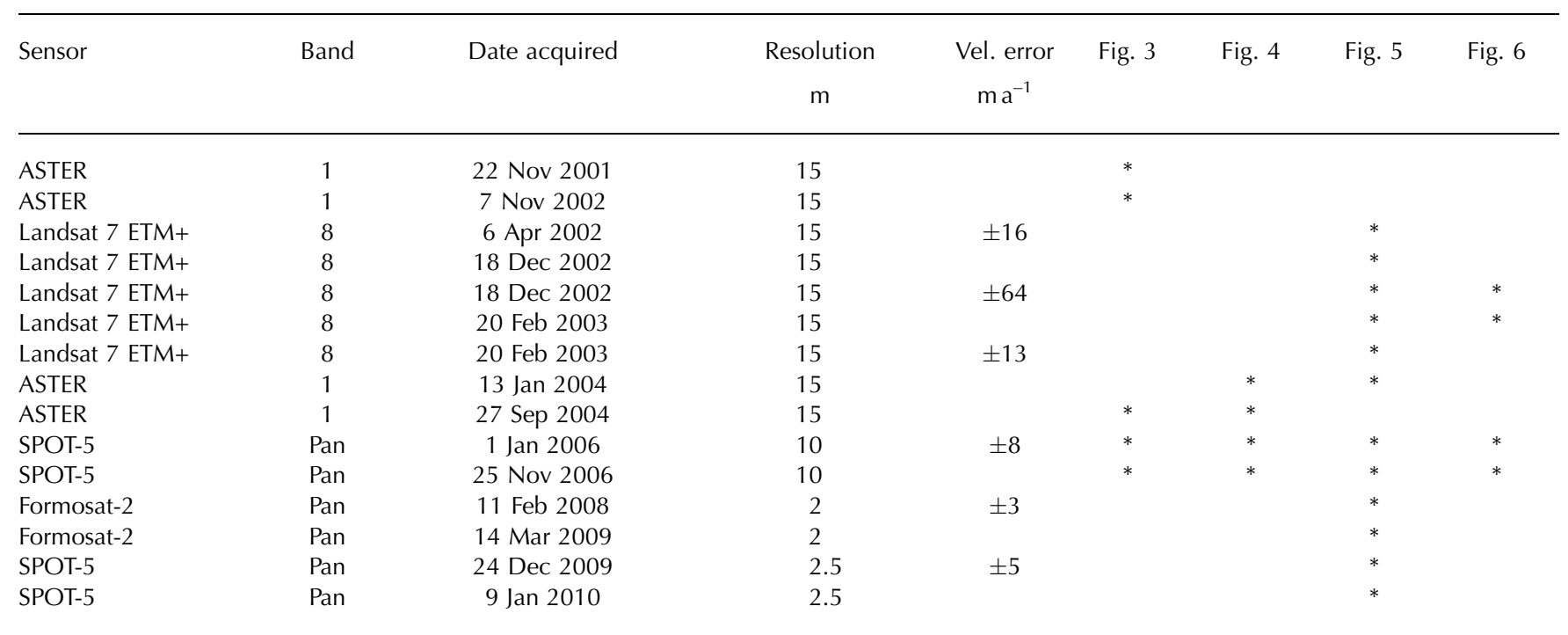

\subsection{Airborne Topographic Mapper (ATM) data}

NASA has operated an airborne laser altimetry system, the ATM, for surveys of ice sheets, glaciers, sea ice and other land and ocean areas since 1991 (Krabill and others, 1995; Abdalati and Krabill, 1999). There have been multiple versions and software adjustments over time, but the basic system remains a helical-scanning pulse laser, operating at $532 \mathrm{~nm}$ (frequency-doubled from a $1064 \mathrm{~nm}$ laser source) with a laser pulse rate of $3 \mathrm{kHz}$. The laser pulses produce a set of dense, overlapping elliptic helical tracks of surface measurements that are processed into along-flight tracks of 'plates', i.e. mean slope and elevation values extracted from the full dataset at $70 \mathrm{~m} \times 70 \mathrm{~m}$ intervals on either side of the flight-line (up to five plates across-track, continuous alongtrack). Errors for the $70 \mathrm{~m} \times 70 \mathrm{~m}$ mean slope and elevation gridcells are a few centimeters under optimum conditions but can be as large as several decimeters (Krabill and others, 1995, 2002). Overflights of the Crane Glacier trunk by the ATM system have occurred on 26 November 2002, 29 November 2004 and 21 October 2008 and on 31 October and 4 November 2009. The 2008 profile did not cross the same point on ICESat track 0018 (see Fig. 1), so a small slope correction was applied to estimate the height at the intersection of the 2002 and 2004 ATM data and the ICESat track 0018 on that date. Offsets between repeats along track 0018 profiles were a few hundred meters. ATM data are available from the NSIDC's Ice Bridge project (nsidc.org/ data/icebridge) and from the University of Kansas Center for Remote Sensing of Ice Sheets (CReSIS: www.cresis.ku.edu).

\subsection{Satellite stereo-image digital elevation models and DEM differencing}

We also generated a series of DEMs of the Crane Glacier trunk and nearby glaciers, from satellite stereo digital images (Table 1). We used six such stereo-image DEMs in evaluating the topographic evolution of lower Crane Glacier. The two sensors used are the Advanced Spaceborne Thermal Emission and Reflection Radiometer (ASTER) flying on NASA's Terra platform, and SPOT-5, the fifth satellite of the Système Probatoire pour l'Observation de la Terre (SPOT) series. Both these satellites acquire along-track stereo imagery by a fore and aft (or nadir and aft) acquisition scheme. The systems have imagery with 15 and $5 \mathrm{~m}$ resolution, respectively, and under ideal conditions can resolve elevations to $\sim 5 \mathrm{~m}$ (Fujisada and others, 2005; Bouillon and others, 2006; Toutin, 2008). However, problems with sky clarity, snow/ice reflectance variations and extreme surface roughness at the pixel scale can reduce this accuracy to a few tens of meters (Berthier and Toutin, 2008), creating elevation 'noise' over short distances (2-5 pixels). In general, the profiles are precise $( \pm 5 \mathrm{~m})$ at averaging scales above 10 pixels. Profiles from the satellite stereo DEMs were extracted along the track of the airborne altimetry, providing greater temporal resolution of along-flow slope changes, albeit with greater vertical 'noise' than the airborne data.

ASTER and SPOT-5 DEMs are automatically derived from stereo imagery without ground control points (Fujisada and others, 2005; Korona and others, 2009) and, thus, may contain horizontal shifts up to $50 \mathrm{~m}$ and altimetric biases up to $15 \mathrm{~m}$ (Berthier and others, 2010). For our reference DEM, the 25 November 2006 SPOT-5 DEM, these biases have been estimated and corrected using ICESat- 1 data acquired during laser period 3G, just 10 days before the acquisition date of the SPOT-5 stereo pair. For each ICESat footprint, the corresponding SPOT-5 DEM elevation was extracted by bilinear interpolation. A vertical bias of $3 \mathrm{~m}$ (standard deviation $5.5 \mathrm{~m}, \mathrm{~N}=558$ ) was corrected. Next, all other DEMs were adjusted to this reference DEM using the (assumed) stable regions outside the fast-changing outlet glaciers; first horizontally by minimizing the standard deviation of the elevation differences (Berthier and others, 2007) and then vertically by minimizing the elevation differences.

\subsection{Image-pair feature-tracking for ice velocity}

Near-infrared and visible band images from several sensors were used to create a series of ice-velocity mappings of lower Crane Glacier by an image-to-image correlation technique (Bindschadler and Scambos, 1991). We use software available at the NSIDC website (IMCORR, at http://nsidc.org/data/ velmap/software.html; see Scambos and others, 1992) except for the December 2009 to January 2010 SPOT-5 velocity field, which was created using the MEDICIS software (Berthier and others, 2005). Six image pairs are used to map the flow speed in a small region near the intersection of the 
ATM and ICESat-1 track 0018 repeat profiles, and two pairs are used to map ice flow before and after the rapid drawdown over a broader region of the lower glacier trunk (Table 1). Errors in the flow speed measurement for an image pair are a function of image co-registration accuracy, image crosscorrelation precision, and the time between the image acquisitions. Image correlation precision is 0.25 pixels for each high-confidence correlation match. Image co-registration error ranges from $\sim 1$ pixel for Landsat-7, $\sim 1$ pixel for ASTER, and $\sim 0.5$ or less for SPOT-5 images.

\section{OBSERVATIONS}

Bathymetry data (Fig. 1) were collected from the RV Nathaniel B. Palmer in March-April 2006 using a multibeam sonar system (Mueller and others, 2006; personal communication from E. Domack, 2011; see http:// www.marine-geo.org/antarctic under NBP0603 cruise). After substantial ice-edge retreat during 2003-04 following the major ice-shelf collapse event in 2002 (Shuman and others, in press), maximum fjord depth at the ice front was $1220 \mathrm{~m}$. The glacier front at that time was afloat, with $\sim 300 \mathrm{~m}$ of water depth below the ice at the center of the ice front. Bathymetric mapping of the seaward portion of the fjord reveals a series of low basins (labeled 1, 2 and 3 in Fig. 1). These basins have smooth flat-lying surfaces and layered sediments and are interpreted as subglacial sediment ponds, i.e. subglacial lake deposits (Mueller and others, 2006; personal communication from E. Domack, 2011). Between the submerged lake basins are significant bathymetric ridges, rising to $950 \mathrm{~m}$ depth between basins 2 and 3 . Ice-front positions digitized from Landsat-7, ASTER and SPOT-5 images used in the velocity mapping (described below) show that the ice front lay near this ridge in late September 2004, just prior to significant elevation and flowspeed changes. It subsequently retreated during late 2004 and $2005, \sim 2 \mathrm{~km}$, to a position that it has more or less maintained for the past several years (see http://nsidc.org/ agdc/iceshelves_images for a detailed series of satellite images covering the region).

A history of elevation over time (December 2001 to late 2009) for the region of the intersection of ICESat- 1 track 0018 and the ATM near-center-line glacier profiles $\left(65.35^{\circ} \mathrm{S}, 62.45^{\circ} \mathrm{W}\right)$ highlights the anomalous elevation loss rate and magnitude at that site between September 2004 and September 2005 (Fig. 2). The disintegration of the Larsen B ice shelf in March 2002 precipitated large changes at the Crane glacier front, and a near-immediate acceleration of the lowermost glacier (Scambos and others, 2004); however, elevation change did not begin at the point of the intersection until sometime after December 2002. The site is $12.3 \mathrm{~km}$ upstream from the pre-break-up grounding line determined in the late 1990s (Rack and Rott, 2004). Between November 2002 and September 2004, elevation loss appears to have been steady at a rate of $23 \mathrm{~m} \mathrm{a}^{-1}$ until September 2004. A closely spaced series of elevation measurements at the site constrain the onset of increased drawdown rate to be near this time, and abrupt (see Fig. 2). Over the next year, the rate of elevation loss averaged $91 \mathrm{~m} \mathrm{a}^{-1}$, ending in late September 2005 or possibly slightly before then. Following September 2005, continued but more moderate elevation loss was $12 \mathrm{ma}^{-1}$. As of this writing, it appears that the elevation loss rate has continued through 2009.

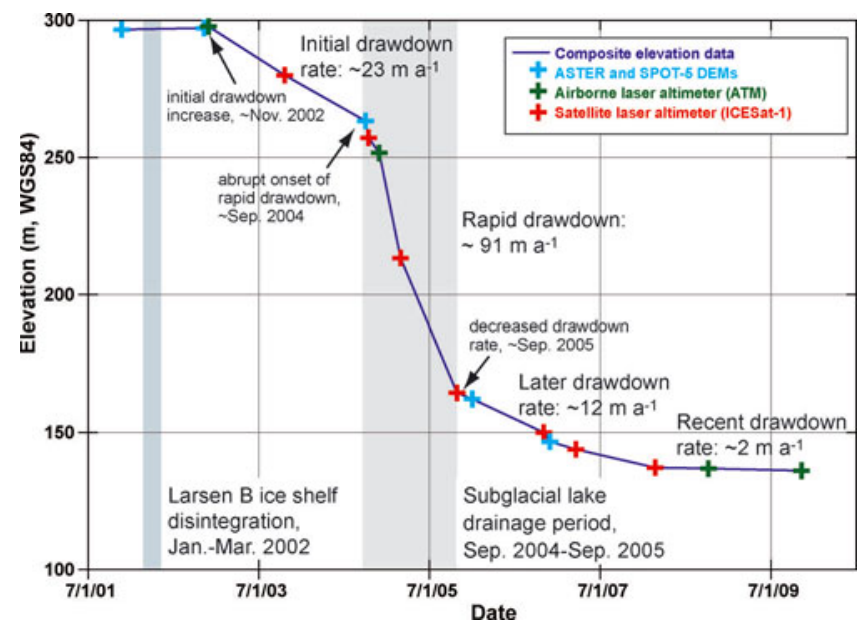

Fig. 2. Elevation change versus time at the intersection of ICESat-1 track 0018 and the ATM laser altimetry ground tracks, near the center of lower Crane Glacier. The elevation datum is the World Geodetic System 1984 (WGS-84) ellipsoid. Dates are month/day/year.

Satellite stereo-image DEMs allow us to examine elevation changes more regionally. A differencing of DEM mappings based on images acquired just prior to increased drawdown (ASTER, 27 September 2004), just after (1 January 2006) and well after (25 November 2006) allows us to examine the regional extent of the abrupt elevation change at the ATM/ICESat 0018 intersection (Fig. 3) over lower Crane Glacier. Differencing of the September 2004 and January 2006 DEMs indicates that the region of abrupt, anomalous elevation change is quite localized, and that the loss there was several tens of meters greater than the loss in the surrounding regions. An outline of a region tracing the maximum gradient in the anomaly encloses a $1.9 \mathrm{~km} \times$ $1.5 \mathrm{~km}$ region (see Discussion). A later difference DEM using the January 2006 and November 2006 SPOT-5 elevation maps shows no evidence of such discrete change in the anomaly region; rather, elevation loss appears to be nearly uniform over the lower trunk, at $\sim 20$ m loss over the interval.

Slope changes along the glacier center line over the elevation-change anomaly provide some insight into the timing and causes of the abrupt elevation loss (Fig. 4). First, differencing elevation profiles from before and after the period of rapid elevation loss (ASTER, 7 November 2002 and SPOT-5, 1 January 2006) indicate a $4.5 \mathrm{~km}$ total extent of the region of anomalous elevation loss, with a maximum of $40 \mathrm{~m}$ additional loss relative to areas upstream (98 $\mathrm{m}$ loss) and downstream (103 m loss; Fig. 4 inset). The $4.5 \mathrm{~km}$ alongflow region spanning the anomalous elevation-loss area shows a slightly increasing surface slope through time, from 0.020 in November 2001 (ASTER DEM prior to shelf breakup) to 0.026 in November 2002 (ATM profiles) as the postshelf break-up effects propagate up-glacier. Slope across the region remains near that value in ASTER DEM longitudinal profiles in January 2004 (0.026) and September 2004 (0.024) that immediately precede the rapid elevation loss. The ATM profile of November 2004 shows an increased slope, to 0.033, at the onset of rapid elevation loss. Data from 2006 and later show much lower slopes, and a significantly changed profile. The October 2008 mean slope is 0.001 . The ATM slope profiles track the development of the surface basin on the glacier, and independently confirm the changes seen in DEM differencing. 


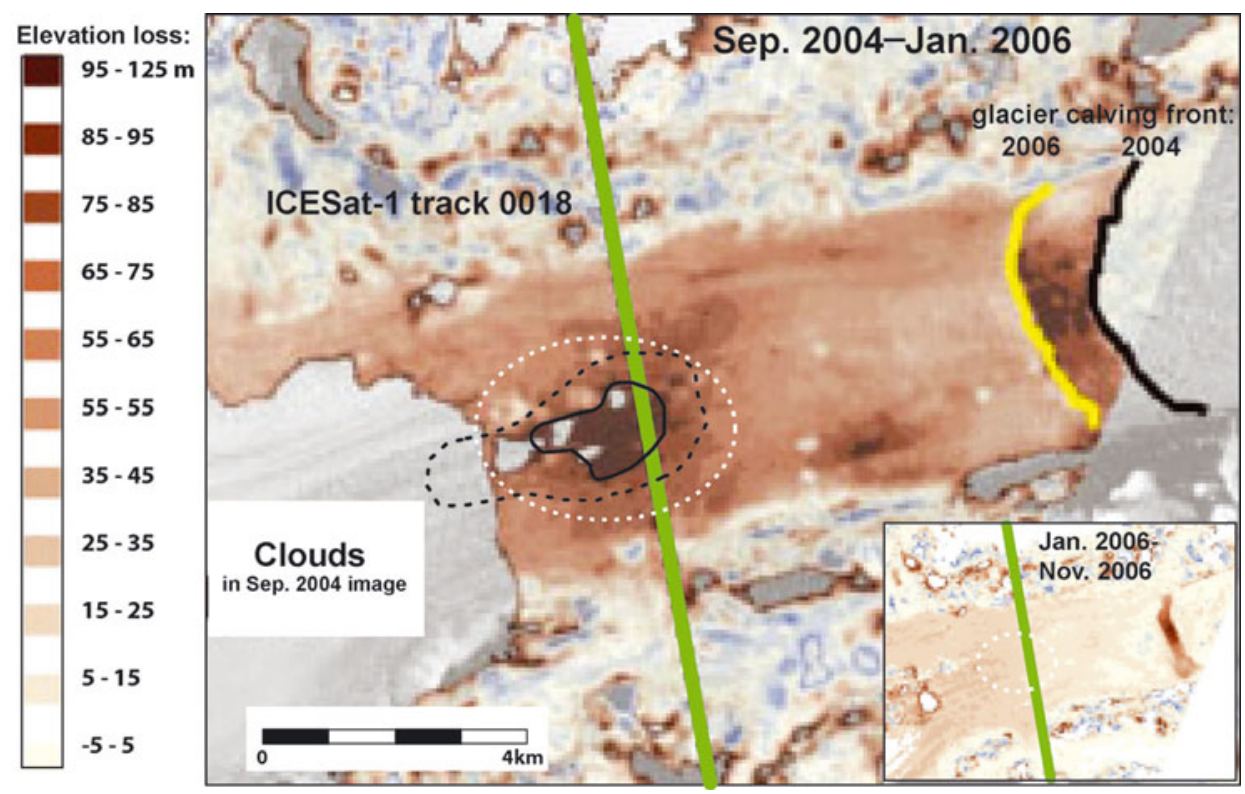

Fig. 3. Elevation change from satellite-image stereo-pair DEM differencing over lower Crane Glacier. Main panel: DEM difference between ASTER image-derived DEMs acquired 27 September 2004 and SPIRIT (SPOT-5 stereoscopic survey of Polar Ice: Reference Images and Topographies) data acquired 1 January 2006. Dashed black outline indicates the limit of anomalous elevation loss from satellite and aircraft altimetry profiles; solid black outline marks the approximate largest gradient in the difference DEM for the region. Inset: SPOT-5 DEM difference of the same area for DEMs acquired 1 January 2006 and 25 November 2006. White dashed line is for reference. Elevation change scale is the same for both panels; mottled blue and pale-brown areas are mountainous regions flanking the glacier.

A very large renewed acceleration of the glacier occurs at the same time (within months) as the sudden elevation loss over the anomaly and retreat of the ice front from the bedrock high (Fig. 5). Speed of the glacier at this site increases rapidly after loss of the ice shelf in early 2002, peaking at $710 \mathrm{~m} \mathrm{a}^{-1}$ in early 2003. Pre-shelf break-up speed in this region of the glacier has been estimated at $300 \mathrm{~m} \mathrm{a}^{-1}$ (Rignot and others, 2004). By late 2003, the glacier begins to slow again, to near $470 \mathrm{~m} \mathrm{a}^{-1}$ (Fig. 5; see also Hulbe and others, 2008).

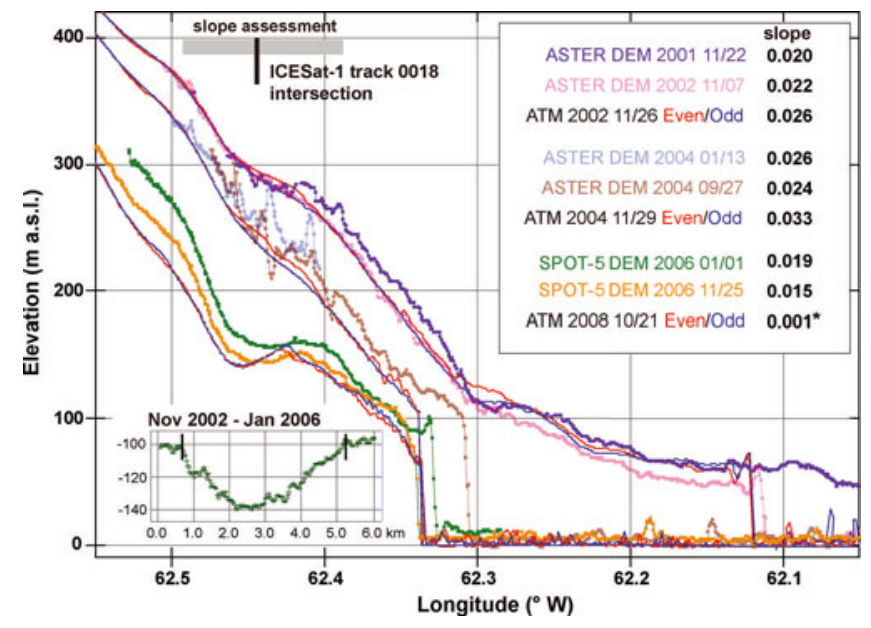

Fig. 4. Along-flow elevation profiles from ATM and satellite stereoimage DEMs for lower Crane Glacier, 2001-08. Red-blue line pairs for ATM data show the range of elevation variation across the swath of ATM laser measurements. Slope values in the inset table are the mean slope for a $4.51 \mathrm{~km}$ region defined by the difference of the November 2002 and January 2006 elevation profiles (lower left inset). Note that the ATM 2008 (asterisked) value is derived from a profile that deviated from the center line significantly (see Fig. 1).
Attempts to use image correlation of image pairs straddling the period of anomalous elevation loss and the last stage of ice-front retreat to measure ice velocity failed because the glacier surface undergoes a large change during this period, dramatically increasing the density and intensity of crevassing. This change occurs over the entire lower trunk of the glacier (Fig. 6). In the SPOT-5 image pair used here just after the lake drainage event (January 2006 and November 2006; Table 1), a very large increase in speed is measured, roughly four times the pre-elevation loss (and

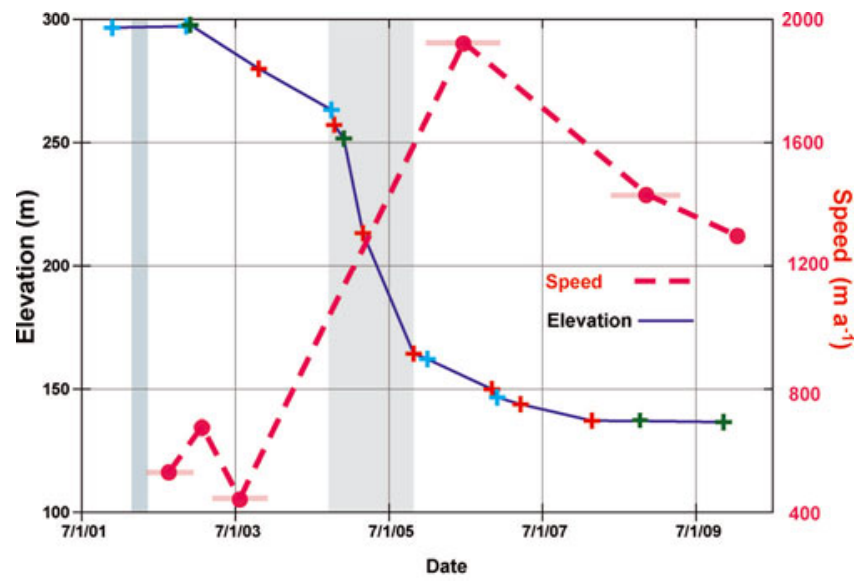

Fig. 5. Elevation changes as in Figure 2, with flow speed changes over time superimposed (right-hand scale). Mean ice speed of the area at the intersection of ICESat- 1 track 0018 and the ATM profiles (Fig. 1) was determined from image pair velocity mapping (Table 1). Horizontal bars for speed determinations represent the time between the image pair acquisitions. Errors in the speed determination are within the symbol size $\left(<30 \mathrm{ma}^{-1}\right)$ except for the December 2002/February 2003 pair $\left( \pm 64 \mathrm{~m} \mathrm{a}^{-1}\right)$. Dates are month/day/year. 
pre-front retreat) speed (to $1943 \mathrm{~m} \mathrm{a}^{-1}$; Fig. 5). By early 2009, this decreased to $1430 \mathrm{~m} \mathrm{a}^{-1}$, as measured by a Formosat-2 image pair (Scambos and Liu, 2009). A SPOT-5 image pair acquired in late 2009 and early 2010 yielded a speed of $1270 \mathrm{~m} \mathrm{a}^{-1}$ in the anomaly region.

As noted above, in the months following the elevation change that began in September 2004, the glacier develops a dense crevasse network extending from near the ice front to $10 \mathrm{~km}$ upstream (Fig. 6). Prior to this time, the glacier surface is relatively uncrevassed and gently undulating (Fig. 6a and b), despite the fact that it had already accelerated by a factor of 3-6 in the aftermath of the Larsen $B$ ice shelf disintegration. The surface character is essentially unchanged between November 2002 and September 2004. As the anomalous elevation loss and most recent significant ice-front retreat begins in late 2004, the surface becomes covered in a dense network of crevasses at several orientations. This is particularly the case in the lowermost $2 \mathrm{~km}$ of the central glacier trunk, where the ice was observed to be afloat in 2006 (see Fig. 1), but the new dense crevasse pattern extends well upstream of the anomalous elevationloss region. This new surface character persists through 2006 (Fig. 6c and d) and was observed on 2009 aircraft flights by one of the authors (C.A.S.).

To examine the potential causes of the secondary (200406) large acceleration and crevasse changes, we further analyzed the ice flow speed of a larger area of the lower Crane Glacier trunk using the best image pairs available (i.e. broadest clear-sky coverage) from the Figure 5 analysis. The selected image pairs for speed analysis in Figure 6 are given in Table 1. Figure $6 \mathrm{~b}$ contains contours from the December 2002/February 2003 image pair. While this pair had a higher potential error for a single vector, the image features correlated very well, providing a dense vector field ( $\sim 4500$ vectors) that reduced the uncertainty of the velocity measurement (smoothing the grid by an inverse square algorithm with $600 \mathrm{~m} \times 600 \mathrm{~m}$ regions containing an average of 16 vectors each reduced the error reported in Table 1 by a factor of 4 ). The Figure $6 \mathrm{~b}$ contours show that acceleration of the glacier in the aftermath of the 2002 Larsen B shelf disintegration was broad and uniform, with little evidence of local variations in basal or lateral shear. The longitudinal gradient in velocity is relatively constant. The 2006 image pair yielded fewer, less uniformly distributed vectors (2340 vectors) due to a rough surface and a longer time period between images. However, the mapped regions in the image pair (contours in Fig. 6c) show a very large additional acceleration of the glacier, roughly 2.5 times the previously mapped flow speed, i.e. an increase of 900-1250 $\mathrm{m} \mathrm{a}^{-1}$. The 2006 mapping also shows a step in the velocity field, rising from 1400 to $1600 \mathrm{~m} \mathrm{a}^{-1}$ in less than $1 \mathrm{~km}$, at a location near the upper part of the elevation-loss anomaly. Differencing the two velocity fields (contours in Fig. 6d) indicates that the largest flow-speed increases occur on the flanks of the glacier, suggesting that the shear margins (the southern side in particular) have narrowed. Flow speed increased by up to a factor of 4 in that area by mid-2006.

\section{DISCUSSION}

The highly localized nature of the elevation drawdown (Fig. 3), and the short temporal duration of the anomalous elevation-change event (Fig. 2), and the marked change in the along-flow profile (Fig. 4) lead us to conclude that the
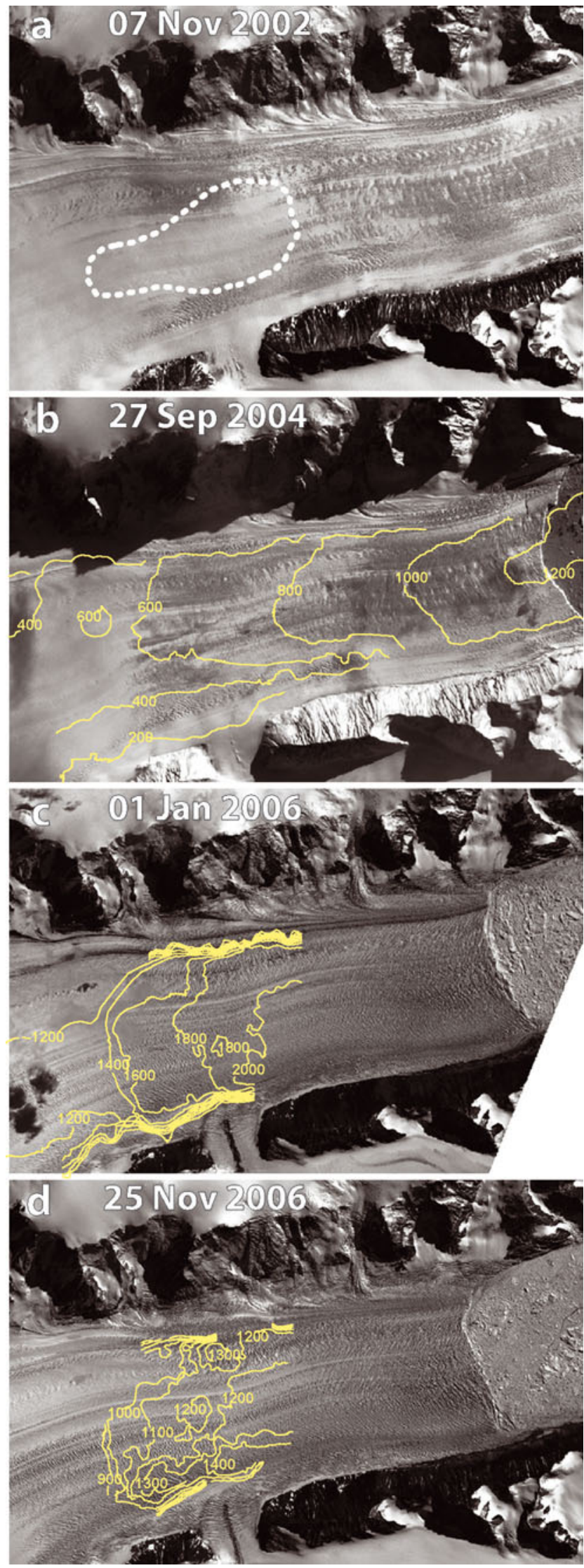

Fig. 6. ASTER (a, b) and SPOT-5 (c, d) image series showing crevasse changes in lower Crane Glacier spanning the period of inferred lake drainage, i.e. between scenes (b) and (c). Superimposed contours are flow speed from December 2002/February 2003 image pair (b), January 2006/November 2006 image pair (c), and the speed difference between the contour fields (d). See Table 1. SPOT-5 images copyright CNES (Centre National d'Études Spatiales, France)/distribution by SPOT image, SPIRIT project. 
primary cause of the anomalous (greater than adjacent areas) elevation change across the center line of lower Crane Glacier was drainage of a kilometer-scale, relatively deep subglacial lake. The lake drainage period was between September 2004 and January 2006. Water depth drained from the subglacial reservoir was likely several tens of meters (Fig. 4 and inset). This subglacial lake appears to be in one of a series of subglacial lake basins in the Crane Glacier fjord, as revealed by the bathymetry (Fig. 1).

Other potential explanations, related to the rapidly changing ice dynamics of Crane Glacier after the loss of the Larsen B ice shelf, cannot fully account for the magnitude and localization of elevation loss over the feature (e.g. Vieli and Nick, 2009). Recent ice models of Crane Glacier's post-ice-shelf-loss responses do not show the anomaly, although they do adequately capture the changes in ice flow and broader changes in thickness and elevation elsewhere along the glacier (Hulbe and others, 2008; Vieli and Nick, 2009).

Estimating the size of the Crane subglacial lake is difficult. Sergienko and others (2007) showed that ice-flow dynamics modify the surface expression of subglacial lake drainage, making it impossible to extract lake shape, size and volume from surface-measurable parameters. This is especially true in cases where the horizontal lake size is comparable to ice thickness. This appears to be the case for Crane Glacier, where ice thickness is of the order of $1000 \mathrm{~m}$ in the lower glacier trunk, and surface expression of the lake extends over $4.5 \mathrm{~km}$ along-flow and $2.2 \mathrm{~km}$ across-flow. In the Sergienko and others (2007) model, moreover, it is shown that surface expression of lake drainage can be much larger than the area of the lake, especially along-flow, and that net surface lowering can be significantly less (in their modeled case, roughly one-third) than the actual depth of subglacial lake level drainage.

Given this, and in the absence of reliable data on ice thickness and bedrock shape, we can only make arbitrary, approximate estimates of the size and depth of the inferred Crane subglacial lake. We believe the following estimates of area and water-level change are conservative in view of the Sergienko and others (2007) study. In Figures 3 and 4 we note the limit of significant surface drawdown anomaly $(4.5 \times 2.2 \mathrm{~km})$, and in Figure 3 we mark the region of maximum gradient in the anomaly boundary $(1.9 \times 1.5 \mathrm{~km})$. Assuming this smaller region is the approximate extent of the lake, and that water depth was on the order of $100 \mathrm{~m}$ (and therefore a volume of $\sim 0.2 \mathrm{~km}^{3}$ ), we explore the significance of the surface slope changes on the upper boundary of the lake, and the events leading to sudden drainage.

If the subglacial lake pressure is equilibrated with the overburden of ice directly above it, the slope of the ice/water interface is governed by a simple relationship related to the ice surface slope (i.e. the change in overlying ice thickness with horizontal distance) and the densities of ice and water:

$$
\alpha_{\text {water }}=-\alpha_{\text {ice }}\left(\rho_{\text {ice }} / \rho_{\text {water }}-\rho_{\text {ice }}\right),
$$

where $\alpha$ is slope and $\rho$ is density for the respective materials (Paterson, 1994). Because surface slope changes with time across the elevation anomaly region, there is a change in the ice/water slope of the upper lake surface. In fact, the slope change at the roof of the lake would be a factor of 11 greater than the ice surface slope change, and in the opposite direction, if the water surface was in equilibrium everywhere with the local ice overburden.
Given the slope values in the table inset in Figure 4, and our approximation of lake size, this implies that the initial, pre ice-shelf break-up lake surface had $\sim 420 \mathrm{~m}$ relief (November 2001: $1.9 \mathrm{~km} \times 0.020 \times 11$ ), rising from upstream to downstream. At the time of drainage, this would have increased to $690 \mathrm{~m}$ (November 2004: $1.9 \mathrm{~km} \times 0.033$ $\times 11$ ). While it is unlikely that the ice above this lake was in full flotation equilibrium (Sergienko and others, 2007), this illustrates that a surface slope change across a subglacially trapped water body has a large effect on its geometry.

As Crane Glacier's slope steepened in response to loss of the ice shelf, the ice/water interface of the subglacial water body was tilted, raising the water level at the downstream boundary of the lake, i.e. at the obstruction to water flow that confined the lake. In our proposed scenario, the water level is raised until the obstruction is breached. The overlying ice was locally floated (i.e. hydraulically lifted) off the bedrock surface, and the lake volume was reduced by drainage. The dam may have been eroded by the drainage; alternatively, short-term details of the ice surface-slope change during drainage (e.g. a brief period of further steepening that is not captured by the series of profiles in Figure 4) pushed $\sim 0.2 \mathrm{~km}^{3}$ of water over the dam.

The Crane Glacier dynamics-driven lake drainage process brings up an important consideration for a feedback for climate-driven outlet glacier changes. This process is likely to be applicable to any glacier with ponded subglacial water bodies, when the glacier is undergoing rapid dynamic changes, and therefore rapid surface slope changes. It is reasonable to suppose that many fjord-confined outlet glaciers have stable water bodies beneath them likely fed by a time-varying combination of surface and subsurface meltwater. In particular, the kinds of changes associated with climate warming (e.g. changes in the floating ice front, loss of contact with pinning points, loss of an ice shelf, or increased calving) accelerate the glacier, steepen its slope and thereby disturb the subglacial hydraulic pressure, pushing any trapped water into the subglacial system and thus reducing the basal shear stress (e.g. Clarke, 2005). This inferred mechanism represents a special case of the several glacial floodwater flow mechanisms discussed by Roberts (2005). The 'type 4' mechanism discussed there is flotation of a sealing ice dam by increased hydrostatic stress, and the inferred mechanism of increase is increased water pressure due to surface or subsurface melt input. Here we claim that the increase in hydrostatic stress was caused by changing surface slope, driving the subglacial water to stress levels that likely exceeded pre-shelf-break-up levels. Such drainage events may have a feedback effect on the glacier, causing a further acceleration and glacier steepening. Such a situation would pose a challenge for modeling of ice-sheet response to climate and ocean warming.

However, our study of the ice-flow speed change before and after the event (Fig. 6) shows that, in this case and perhaps generally, subglacial water drainage and movement produces relatively small changes in overall glacier speed, when compared to those caused by ice-front retreat or interactions with subglacial ridges or ice shelves. This pattern of rapid speed increase and slower decline, both in relative magnitude and in timing, matches the response characteristics of the similarly sized southeast Greenland glaciers Helheim and Kangerdlugssuaq (compare Fig. 5 to Howat and others, 2007; Nick and others, 2009) as they dynamically responded to ice-front retreats. 
The Crane Glacier case here offers an opportunity to test the relative impact of two near-simultaneous events: icefront retreat from a bedrock ridge, and the drainage of a significant volume of water at mid-trunk, both initiated in late 2004. In Figure 6 the ice-speed contours and speed difference contours show that the far greater effect is a general acceleration of the entire lower trunk (Fig. 6c and d contours), both above and below the location of the lake. The dramatic crevasse-pattern changes confirm this, and extend across and upstream of the inferred lake area. Small features in the contours of ice-velocity change (Fig. 6d) near the upstream end of the lake indicated a $\sim 20 \%$ net effect on flow speed change that may be associated with the subglacial lake drainage.

\section{CONCLUSIONS}

A rapid, localized elevation change in the lower central portion of Crane Glacier appears to be a result of subglacial lake drainage of a previously unknown lake beneath it. Source water for the lake was probably some combination of basal melting due to strain heating and surface meltwater that has drained through the ice upstream via hydrofracturing. We do not yet observe any evidence for refilling, and the reservoir seal may be permanently compromised by the forced drainage. Bathymetric data and the discovery of sediments in basins within the newly opened fjord suggest that the new lake is one of a series of past subglacial water bodies. The Crane Glacier subglacial lake drainage was apparently triggered by surface slope changes along the glacier center line during glacier retreat (Fig. 4). Specifically, the retreat of the ice front from the subglacial ridge near $62.28^{\circ} \mathrm{W}$ in late 2004 (Fig. 1) appears to have caused a final further change in surface slope, that initiated rapid water discharge from the subglacial reservoir.

The pattern of ice-speed change, both temporally and spatially, supports the idea that glacier interaction with subglacial fjord topography and ice-front retreat across bedrock highs are the dominant control on ice flow and mass flux in outlet glaciers, and that subglacial water is of secondary importance. This high level of response to retreat from bedrock or pinning-point features has been identified for tidewater outlet glaciers everywhere (Meier and Post, 1987; Joughin and others, 2003; Howat and others, 2007; Jenkins and others, 2008; Nick and others, 2009). Conversely, subglacial hydrologic changes, even significant ones, are at most (to date) a $20 \%$ effect on outlet glacier speed (Zwally and others, 2002b; Joughin and others, 2008; Stearns and others, 2008).

\section{ACKNOWLEDGEMENTS}

This research was supported by NASA grant NNG05GO82G to T. Scambos. E. Berthier acknowledges support from the French Space Agency (CNES) through the TOSCA and ISIS proposal No. 352. SPOT-5 high-resolution stereo data were provided at no cost by CNES through the SPIRIT International Polar Year project (Korona and others, 2009). ASTER data were provided at no cost by NASA/US Geological Survey through the Global Land Ice Measurements from Space (GLIMS) project (Raup and others, 2007). Formosat-2 data used in the study (Fig. 5) were acquired by the National Space Projects Office (NSPO) of Taiwan, and processed by Chien-Cheng Liu of National Cheng-Kung
University, Tainan, Taiwan. Bathymetry data were facilitated by F. Zgur and M. Rebesco. We thank J. Bohlander and T. Haran of NSIDC, who produced several of the datasets used in the study, and V. Suchdeo (Sigma Space at NASA Goddard Space Flight Center) who assisted with the ATM data processing.

\section{REFERENCES}

Abdalati, W. and W.B. Krabill. 1999. Calculation of ice velocities in the Jakobshavn Isbræ area using airborne laser altimetry. Remote Sens. Environ., 67(2), 194-204.

Bell, R.E., M. Studinger, C.A. Shuman, M.A. Fahnestock and I. Joughin. 2007. Large subglacial lakes in East Antarctica at the onset of fast-flowing ice streams. Nature, 445(7130), 904-907.

Berthier, E. and T. Toutin. 2008. SPOT5-HRS digital elevation models and the monitoring of glacier elevation changes in North-West Canada and South-East Alaska. Remote Sens. Environ., 112(5), 2443-2454.

Berthier, E. and 7 others. 2005. Surface motion of mountain glaciers derived from satellite optical imagery. Remote Sens. Environ., 95(1), 14-28.

Berthier, E., Y. Arnaud, R. Kumar, S. Ahmad, P. Wagnon and P. Chevallier. 2007. Remote sensing estimates of glacier mass balances in the Himachal Pradesh (Western Himalaya, India). Remote Sens. Environ., 108(3), 327-338.

Berthier, E., E. Schiefer, G.K.C. Clarke, B. Menounos and F. Rémy. 2010. Contribution of Alaskan glaciers to sea-level rise derived from satellite imagery. Nature Geosci., 3(2), 92-95.

Bindschadler, R.A. and T.A. Scambos. 1991. Satellite-imagederived velocity field of an Antarctic ice stream. Science, 252(5003), 242-246.

Bo, S. and 8 others. 2009. The Gambursev mountains and the origin and early evolution of the Antarctic Ice Sheet. Nature, 459(7247), 690-693.

Bouillon, A., M. Bernard, P. Gigord, A. Orsoni, V. Rudowski and A. Baudoin. 2006. SPOT 5 HRS geometric performances: using block adjustment as a key issue to improve quality of DEM generation. ISPRS J. Photogramm. Rem. Sens., 60(3), 134-146.

Clarke, G.K.C. 2005. Subglacial processes. Annu. Rev. Earth Planet. Sci., 33, 247-276.

Fricker, H.A. and T. Scambos. 2009. Connected subglacial lake activity on lower Mercer and Whillans Ice Streams, West Antarctica, 2003-2008. J. Glaciol., 55(190), 303-315.

Fricker, H.A., T. Scambos, R. Bindschadler and L. Padman. 2007. An active subglacial water system in West Antarctica mapped from space. Science, 315(5818), 1544-1548.

Fujisada, H., G.B. Bailey, G.G. Kelly, S. Hara and M.J. Abrams. 2005. ASTER DEM performance. IEEE Trans. Geosci. Remote Sens., 43(12), 2707-2714.

Gray, L., I. Joughin, S. Tulaczyk, V.B. Spikes, R. Bindschadler and K. Jezek. 2005. Evidence for subglacial water transport in the West Antarctic Ice Sheet through three-dimensional satellite radar interferometry. Geophys. Res. Lett., 32(3), L03501. (10.1029/2004GL021387.)

Howat, I.M., I.R. Joughin and T.A. Scambos. 2007. Rapid changes in ice discharge from Greenland outlet glaciers. Science, 315(5818), 1559-1561.

Hulbe, C.L., T.A. Scambos, T. Youngberg and A.K. Lamb. 2008. Patterns of glacier response to disintegration of the Larsen B ice shelf, Antarctic Peninsula. Global Planet. Change, 63(1), 1-8.

Jenkins, A. and 6 others. 2008. Observations beneath Pine Island Glacier in West Antarctica and implications for its retreat. Nature Geosci., 3(7), 468-472.

Joughin, I., E. Rignot, C.E. Rosanova, B.K. Lucchitta and J. Bohlander. 2003. Timing of recent accelerations of Pine Island Glacier, Antarctica. Geophys. Res. Lett., 30(13), 1706. (10.1029/ 2003GL017609.) 
Joughin, I., S.B. Das, M.A. King, B.E. Smith, I.M. Howat and T. Moon. 2008. Seasonal speedup along the western flank of the Greenland Ice Sheet. Science, 320(5877), 781-783.

Korona, J., E. Berthier, M. Bernard, F. Rémy and E. Thouvenot. 2009. SPIRIT. SPOT 5 stereoscopic survey of Polar Ice: reference images and topographies during the fourth International Polar Year (2007-2009). ISPRS J. Photogramm. Rem. Sens., 64(2), 204-212.

Krabill, W.B., R.H. Thomas, C.F. Martin, R.N. Swift and E.B. Frederick. 1995. Accuracy of airborne laser altimetry over the Greenland ice sheet. Int. J. Remote Sens., 16(7), 1211-1222.

Krabill, W.B. and 8 others. 2002. Aircraft laser altimetry measurements of changes of the Greenland ice sheet: technique and accuracy assessment. J. Geodyn., 34(3-4), 357-376.

Meier, M.F. and A. Post. 1987. Fast tidewater glaciers. J. Geophys. Res., 92(B9), 9051-9058.

Mueller, R.D. and 6 others. 2006. Ocean/ice-shelf interactions around collapsing Antarctic Peninsula Ice Shelves. EOS, 87(52).

Nick, F.M., A. Vieli, I.M. Howat and I. Joughin. 2009. Large-scale changes in Greenland outlet glacier dynamics triggered at the terminus. Nature Geosci., 2(2), 110-114.

Paterson, W.S.B. 1994. The physics of glaciers. Third edition. Oxford, etc., Elsevier.

Pattyn, F. 2010. Antarctic subglacial conditions inferred from a hybrid ice sheet-ice stream model. Earth Planet. Sci. Lett., 295(3-4), 451-461.

Rack, W. and H. Rott. 2004. Pattern of retreat and disintegration of the Larsen B ice shelf, Antarctic Peninsula. Ann. Glaciol., 39, 505-510.

Raup, B. and 11 others. 2007. Remote sensing and GIS technology in the Global Land Ice Measurements from Space (GLIMS) Project. Comput. Geosci., 33(1), 104-125.

Rémy, F. and B. Legrésy. 2004. Subglacial hydrological networks in Antarctica and their impact on ice flow. Ann. Glaciol., 39, 67-72.

Rignot, E., G. Casassa, P. Gogineni, W. Krabill, A. Rivera and R. Thomas. 2004. Accelerated ice discharge from the Antarctic Peninsula following the collapse of Larsen B ice shelf. Geophys. Res. Lett., 31(18), L18401. (10.1029/2004GL020697.)

Roberts, M.J. 2005. Jökulhlaups: a reassessment of floodwater flow through glaciers. Rev. Geophys., 43(RG1), RG1002. (10.1029/ 2003RG000147.)

Scambos, T. and C.-C. Liu. 2009. A closer look at polar ice: Formosat-2 and glacier changes in the Arctic and Antarctic. In Proceedings of the Formosat-2 5th Anniversary Conference, 19-21 May 2009. Hshinchu, Taiwan. Hshinchu, Taiwan National Space Organization (NSPO), 24-33.

Scambos, T.A., M.J. Dutkiewicz, J.C. Wilson and R.A. Bindschadler. 1992. Application of image cross-correlation to the measurement of glacier velocity using satellite image data. Remote Sens. Environ., 42(3), 177-186.

Scambos, T.A., J.A. Bohlander, C.A. Shuman and P. Skvarca. 2004. Glacier acceleration and thinning after ice shelf collapse in the Larsen B embayment, Antarctica. Geophys. Res. Lett., 31(18), L18402. (10.1029/2004GL020670.)

Schutz, B.E., H.J. Zwally, C.A. Shuman, D. Hancock and J.P. DiMarzio. 2005. Overview of the ICESat Mission. Geophys. Res. Lett., 32(21), L21S01. (10.1029/2005GL024009.)

Sergienko, O.V., D.R. MacAyeal and R.A. Bindschadler. 2007 Causes of sudden, short-term changes in ice-stream surface elevation. Geophys. Res. Lett., 34(22), L22503. (10.1029/ 2007GL031775.)

Shabtaie, S. and C.R. Bentley. 1988. Ice-thickness map of the West Antarctic ice streams by radar sounding. Ann. Glaciol., 11 126-136.

Shuman, C.A. and 6 others. 2006. ICESat Antarctic elevation data: preliminary precision and accuracy assessment. Geophys. Res. Lett., 33(7), L07501. (10.1029/2005GL025227.)

Shuman, C.A., E. Berthier and T. Scambos. 2011. 2001-2009 elevation and mass losses in the Larsen A and B embayments, Antarctic Peninsula. J. Glaciol., 204.

Siegert, M.J., S. Carter, I. Tabacco, S. Popov and D.D. Blankenship. 2005. A revised inventory of Antarctic subglacial lakes. Antarct. Sci., 17(3), 453-460.

Smith, B.E., H.A. Fricker, I.R. Joughin and S. Tulaczyk. 2009. An inventory of active subglacial lakes in Antarctica detected by ICESat (2003-2008). J. Glaciol., 55(192), 573-595.

Stearns, L.A., B.E. Smith and G.S. Hamilton. 2008. Increased flow speed on a large East Antarctic outlet glacier caused by subglacial floods. Nature Geosci., 1(12), 827-831.

Toutin, T. 2008. ASTER DEMs for geomatic and geoscientific applications: a review. Int. J. Remote Sens., 29(7), 1855-1875.

Vieli, A. and F. Nick. 2009. Understanding dynamic changes of marine terminating outlet glaciers through combining observations and numerical modeling: the case of Crane Glacier, Antarctic Peninsula. [Abstract C13A-06.] Eos, 90(52), Fall Meet Suppl.

Wingham, D.J., M.J. Siegert, A. Shepherd and A.S. Muir. 2006 Rapid discharge connects Antarctic subglacial lakes. Nature, 440(7087), 1033-1036.

Zwally, H.J. and 15 others. 2002a. ICESat's laser measurements of polar ice, atmosphere, ocean and land. J. Geodyn., 34(3-4), 405-445.

Zwally, H.J., W. Abdalati, T. Herring, K. Larson, J. Saba and K. Steffen. 2002b. Surface melt-induced acceleration of Greenland ice-sheet flow. Science, 297(5579), 218-222. 